\title{
Evaluation on Water Resources and Determining the Values of Exported and Imported Virtual Water in Hashtgerd Region
}

\author{
Seyed Jalal Yadollahi Nooshabadi, Mohammad Reza Jahansuz*, \\ Nasser Majnoun Hosseini, Gholam Reza Peykani \\ College Agriculture \& Natural Resources, University of Tehran, Karaj, Iran

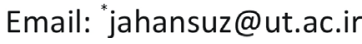

Received 16 January 2016; accepted 16 May 2016; published 19 May 2016

Copyright (C) 2016 by authors and Scientific Research Publishing Inc.

This work is licensed under the Creative Commons Attribution International License (CC BY). http://creativecommons.org/licenses/by/4.0/

c) (i) Open Access

\begin{abstract}
The concept of virtual water in recent years has been proposed with the world's water resource consumption management approach. Hashtgerd study area is one of 609 study areas of the country that is located entirely in Alborz Province. Average annual rainfall in this region was about 200 to $340 \mathrm{~mm}$ and the average agricultural production per year was more than one million tons and had more than 16 million cubic meters surplus recovery from underground water resources. The aim of this study is to evaluate resources and amounts of virtual water in the agricultural sector of the study area and its impact on the area water resources balance and ultimately provide solutions to reduce water consumption by the agricultural sector. The most important exported water products in Hashtgerd area in order of importance are peaches and nectarines $133 \%$ of water exports), plums (15\% of water exports), vegetables (5.14 percent of water exports), cherry (4.7\% of water exports) and wheat (6.5 percent of water exports). Virtual water trade balance of agricultural and horticultural products in the digital range is equal to $260+$ million cubic meters. Density of agricultural lands can be mentioned as the main reasons for positive balance of virtual water trade in this area.
\end{abstract}

\section{Keywords}

Virtual Water, Agriculture, Consumption, Hashtgerd

\section{Introduction}

The concept of virtual water was presented for the first time by Tony Allen in 1993, as total consumed water to

${ }^{*}$ Corresponding author.

How to cite this paper: Nooshabadi, S.J.Y., Jahansuz, M.R., Hosseini, N.M. and Peykani, G.R. (2016) Evaluation on Water Resources and Determining the Values of Exported and Imported Virtual Water in Hashtgerd Region. Open Journal of Ecology, 6, 366-376. http://dx.doi.org/10.4236/oje.2016.66035 
produce a certain quantity of the product as commodity, agricultural products and/or services. Researchers with the introducing the results indicate that interior water resources of a country can supply its water needs or each country how much depends on water resources of exporting products countries [1] [2].

Many countries in arid and semi-arid regions have surplus recovery from renewable water resources to manage food security and food self-sufficiency. Virtual water trade can reduce the crisis of water resources, provided that the countries with water resources limitation have the ability to import food from countries with high water resources [3].

Hukstra and Hang (2002) stated that total water consumption inside a country was not alone proper criterion of its actual recovery of that country from global water resources. In fact, the volume of imported virtual water should be added to the total internal water consumption so that a true picture of the real needs of a country to global water resources to be drawn. And also, the volume of exported virtual water should be less than the volume of internal water consumption. They introduced total net imports of virtual water and internal water consumption as water ecological footprint of a country, which was an indicator to determine the actual consumption of water [1] [2] [4]. Iran has a very inhomogeneous distribution of water resources in the country. In this case, intra-countries virtual water trade between provinces and even townships by spending less can solve a major part of problems in the water distribution [5].

Water use efficiency of all agriculture and horticulture products in Alborz province is higher than national average and even more often higher than all provinces of the country. It is considered in this study that in addition to clarification capacities, policies and perspectives of soil and water of study area using virtual water concept and existing agricultural production statistics, water use in agriculture is to be analyzed widely [6].

The aim of this study is to evaluate resources and amounts of virtual water in the agricultural sector and its impact on water resources balance in the study area of Hashtgerd. In fact, the present study monitors consumption management and examines its impact on water resources.

\section{Materials \& Methods}

Water national document data, the book of estimate of water requirements of major agricultural and horticultural plants written by Farshi and colleagues and food consumption capita statistics have been used for net irrigation water need of agricultural plants [3]. Therefore some tables have been prepared which have been calculated water consumption of different products and overall, compute water consumption of entire agricultural sector, but the important point is that the obtained number must be consistent with the realities of the region's water, so it is necessary that tables to be calibrated in such a way to establish micro and macro communications of agricultural sector in an appropriate and realistic way.

Regarding to the production of all agricultural, horticultural and livestock products in the study area in 20132014 using the concept of water stored in the products calculation of total water consumption in agricultural sector has been studied separately. Also capacities savings and priority management have been identified. Following considerations have been regarded to accomplish the calculations:

1) Almost all produced products in the area (Agriculture and horticulture) have been considered.

2) Virtual water trade with a positive sign means exports and with negative sign means imports.

3) In the case of agricultural and horticultural products that their capita consumption does not exist in a way of country have used FAO statistics and their related offices in Jahade Keshavarzi Ministry, and it has been considered equal for all the years.

Great care has been taken to calculate required water and water consumption of agricultural products (which is very important). But comprehensive and accurate information in some cases has not been available because the lack of studies and data recording systems (such as lack of observational wells and groundwater resources quality monitoring system).

\subsection{Under Study Area}

The whole country has been consisted of 6 main watershed areas and 30 watershed of 2 degree. In the other divisions, the whole country has been divided into 609 different studied areas. Hashtgerd studied area (4105 code) is included one of 609 studied area of country and parts of the watershed of 2 degree, as lake of salt watershed (Code 41). 
Under study area of Hashtgerd has been located in the northern half of salt lake watershed, area of mountains and plains in this area are 579 and 6.591square kilometers (a total of 1170.6 square kilometers), respectively and maximum and minimum height of 4058 and 1133 meters, respectively [7].

This under study area consists of parts of the two city of Savojbolagh (Alborz province garden pole) and Nazar Abad (Region Agricultural pole) and more than 90\% of agricultural lands of these city. In this study, the data related to these two city considered as Hashtgerd data for the under study area. From the most important of the sections in studied area can be referred to Chandar, Tankaman, Charbaghand Markazi (Figure 1).

Also, most important river in the studied area is the Kurdan river. Economic and political position in this region because of Tehran Mega polis, and localization of a large number of industrial, service units, and major agricultural centers in the area, all lead to large force be pressured on the available water resources.

The total number of beneficiaries in the studied area which has been achieved from the beneficiaries of Nazarabad (3800) and Savojbolagh $(13,000)$ is about 16800 and share of the agricultural sector employed is $6.7 \%$ of the total area population (220 million people).

With an overview of the current status of agriculture in the region of Hashtgerd and compared with provincial and national statistics, will have been considered the following points:

1) Agricultural products' performance often is more than provincial and national mean and according to Ministry of Agriculture, record of national wheat production is $5 / 13$ tons per hectare belongs to NazarAadi farmer.

2) Most of the cultivation and production of horticultural products of Alborz province is in this range. International record of 70 tons per hectare is recorded by the Savojbolagh farmer.

3) The per capita income of each exploiter in agricultural section is more than per capita mean income of each

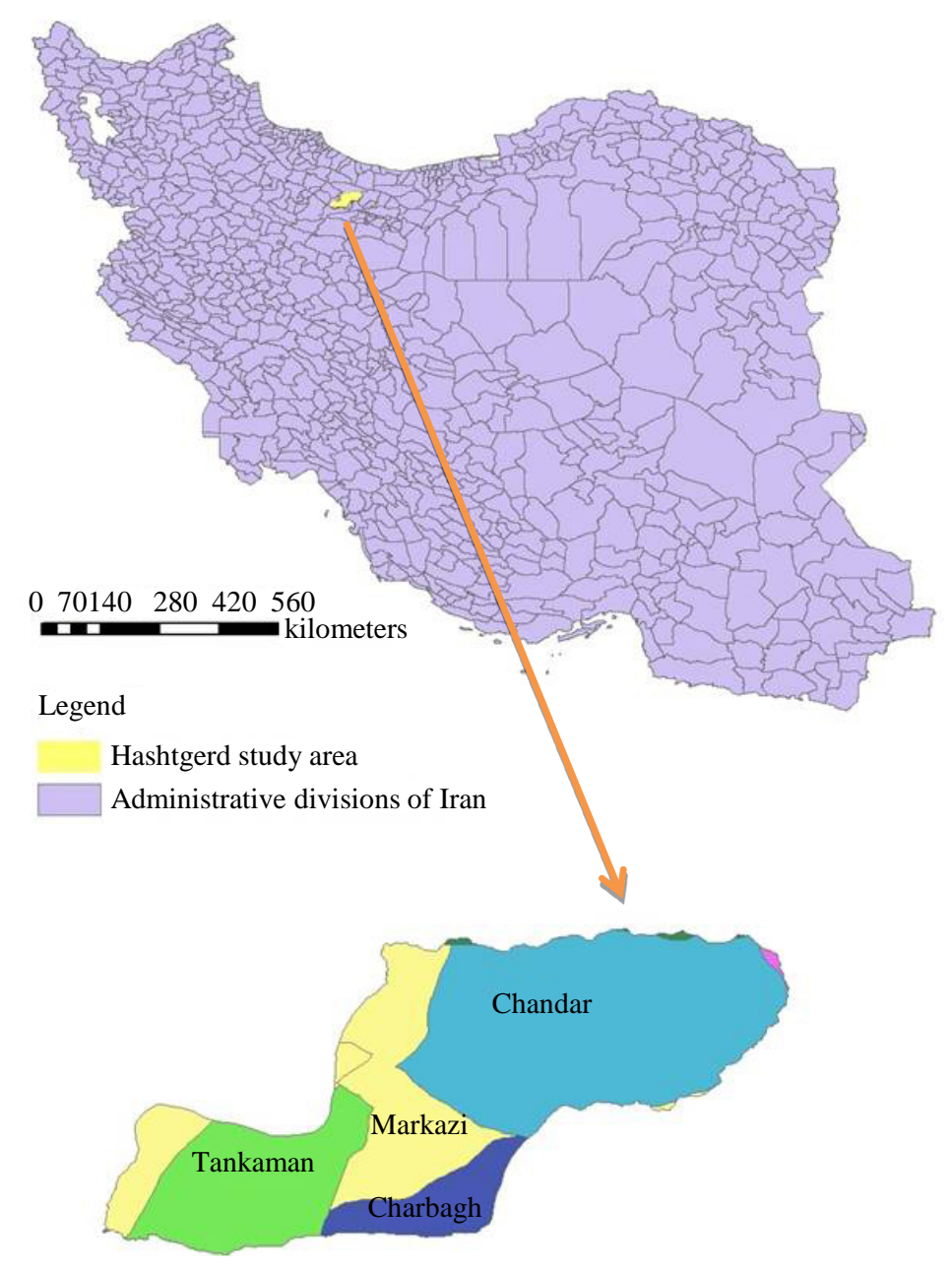

Figure 1. The geographical coordinates of the study area of Hashtgerd. 
exploiter in range of national section. The feature means production of products by high economic value inside and import of water consuming production by lower economic value is of populated and low water regions of world [8].

\subsection{Computation of Water Consumption}

Farshi and colleagues have calculated the amount of pure water of each agricultural and horticultural production for Karaj province by reduction of supplied water of rain from total pure water required to plant [3]. Calculation of amount of consumption water of each plant in the region Hashtgerd is done based on cropping patterns and use of multiplying cultivated of each plant by pure water need.

\section{Results and Discussion}

\subsection{Surrounding Water Resources and Water Balance}

Exploiter resources of groundwater in the research area contains 6661 wells with an annual discharge 98/318 million cubic meters, 204 spring bit with an annual discharge 65/5 million cubic meters and 18 aqueduct with an annual discharge 73/3 million cubic meters (Table 1).

Volume of water consumption in the study area equals to 363.06 million cubic meters a year which is 320.3 million cubic meters of groundwater (wells and aqueducts) and 42.76 million cubic meters of surface flows and spring that used respectively 330.81 million cubic meters (91\%) in agriculture, 24.27 million cubic meters (7\%) in consumption and 7.98 million cubic meters (2\%) in industry (Table 2).

Balance, is balance between properties and harvesting and about water resources between input and output factors of water in a watershed, a study area or an aquifer in certain time. The balance results of groundwater include volume belongs to each component of recharging and discharging aquifer and alluvial aquifer storage volume change has presented in Table 3.

However, the amount of change in firm storages of surface and groundwater should be balanced between input and output factors. Therefore the total output factors of general balance of water in the study area Hashtgerd equals to 302.39 million cubic meters which is more compared to 16.02 million cubic meters of input factors, that the volume equals to reduction volume of alluvial aquifer of Hashtgerd plain, which the extra recovery of firm storage of alluvial aquifer is recovered from Hashtgerd plain.

\subsection{Water Consuming of Agricultural Section of Major View}

Of the most major cultivated agricultural productions in Hashtgerd area can be aligned respectively 29.4 percent, 24.7 percent and 21 percent to wheat, forage maize and barely and in horticultural productions 21.5 percent is to nectarines, 21.2 percent to peach and 10 percent to apple.

According to Tehran regional water company in the crop year 2013-2014, the amount of water consumption in agricultural section in the study area is about 331 million cubic meters (15.91\%) of total 363 million cubic meters of consumed water. According to the present study total of consumption water in agricultural (without considering livestock products) section is about 339 million cubic meters. The deference of 8 million cubic meters is due to in the study two cities are considered Sovojbolagh and Nazarabad, while the study area has the less extensive

10 major water consumption products include respectively peach and nectarines, forage maize, wheat, barely, types of plums, cabbage and lettuce, alfalfa, apples, cherries and grapes which are more than $86 \%$ of water consumption of agricultural and horticultural.

Based on Water Resources Management Company report in Alborz, the most of groundwater withdrawals has been on Hashtgerd plain and the amount of $43.4 \%$ of total water withdrawal. The amount of 51.4 of total water withdrawal from groundwater resources is used for agricultural consumption, it should be noted that the plain is of banned plains.

\subsection{Cultivated Area and the Levels of Agricultural Production}

Cultivated area and percentage of agricultural and horticultural productions in range of 2013-2014 has been presented in Table 4. Cultivated area of agricultural crops had been 35818 hectares in the based year. 
Table 1. Number and depletion of groundwater resources in the plains and heights (depletion numbers in million cubic meters).

\begin{tabular}{cccccccccc}
\hline \multicolumn{2}{c}{ Alluvial aquifer } & \multicolumn{2}{c}{ Total of area } & \multicolumn{2}{c}{ Heights } & \multicolumn{2}{c}{ Plain } & Source type \\
\hline Discharge & Number & Discharge & Number & Discharge & Number & Discharge & Number & \\
\hline $\mathbf{8 4 . 3 0 6}$ & 3697 & 98.318 & 6661 & 93.3 & 1330 & 05.315 & 5331 & Well \\
$\mathbf{0}$ & 0 & 35.5 & 204 & 25.5 & 198 & 1.0 & 6 & Fountain \\
$\mathbf{0}$ & 1 & 73.3 & 18 & 95.0 & 1 & 78.2 & 17 & Aqueduct \\
$\mathbf{8 4 . 3 0 6}$ & 3698 & 06.328 & 6883 & 13.10 & 1529 & 9.317 & 5354 & Sum \\
\hline
\end{tabular}

Table 2. Water consumption and its supplier resources for each plain and heights (million cubic meters).

\begin{tabular}{cccccccc}
\hline \multirow{2}{*}{ Sum } & \multicolumn{2}{c}{ Surface flow and springs } & \multicolumn{2}{c}{ Groundwater sources (wells and aqueducts) } & Area \\
\hline & Agriculture & Industry & Drinking & Agriculture & Industry & Drinking & \\
\hline $\mathbf{3 1 . 3 3 7}$ & 41.21 & 0 & 0 & 17.186 & 43.7 & 3.22 & Plain \\
$\mathbf{7 5 . 2 5}$ & 31.20 & 01.0 & 03.1 & 92.2 & 54.0 & 94.0 & Heights \\
$\mathbf{4 7 . 3 1 3}$ & 64.6 & 0 & 0 & 64.280 & 06.7 & 14.19 & Alluvial aquifer \\
$\mathbf{0 6 . 3 6 3}$ & 72.41 & 01.0 & 03.1 & 09.289 & 97.7 & 24.23 & Range \\
\hline
\end{tabular}

Table 3. Balance of groundwater alluvial aquifer.

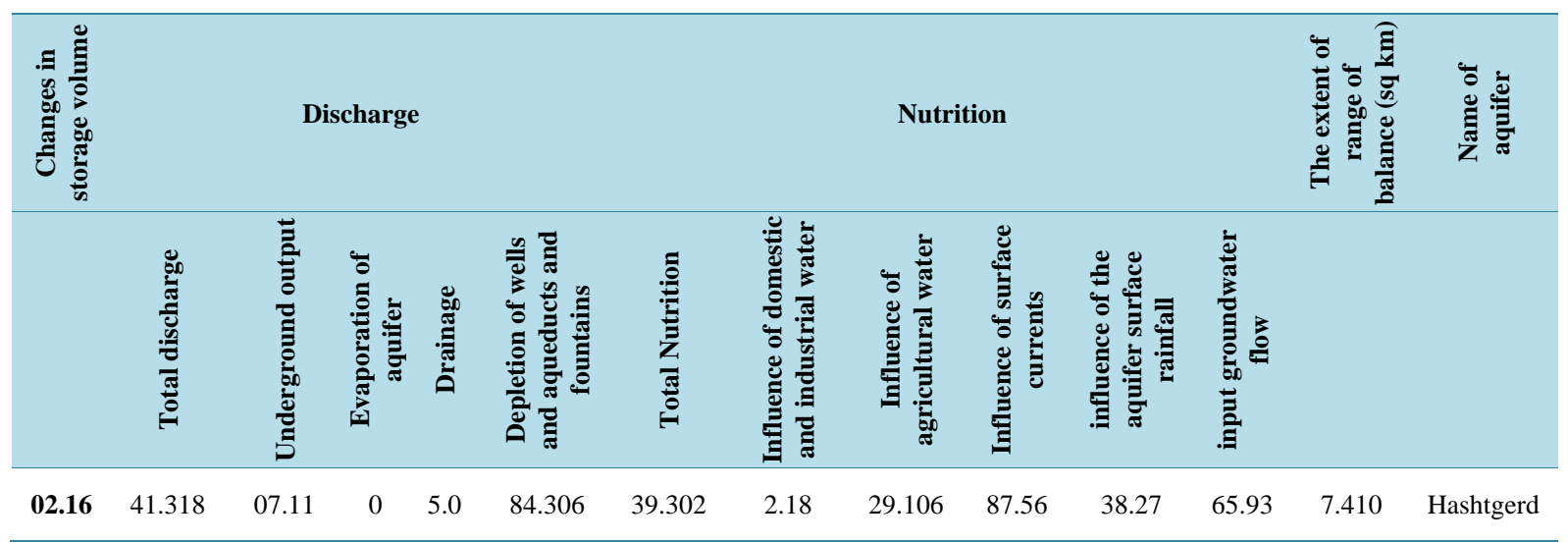

About 75 percent of the area under cultivated of agricultural crops in Alborz province (Table 4) is located in two cities Nazar Abad (53\%) and Savojbolagh (22 percent). The reason of centralization of cultivation in these cities must be searched in quality and quantity of their water resources.

About 56 percent of the city’s gardens are located in Savojbolagh. Totally (figure), two cities of Nazar Abad (37\%) and Savojbolagh (34\%) constitute approximately 71 percent of the area under cultivated of agricultural crops. Nearly all of agricultural lands cultivated the study area as watery in the crop year of 2013-2014.

In the year, amount of agricultural products have been 1165213 tons and the overall amount of horticultural products have been 383,627 tons which is included irrigated and rainy products.

About 51 percent of area which covered by greenhouses in the province and $52 \%$ of greenhouse products in Hashtgerd the study area has been located in the province. Total of cultivated area of greenhouse products are about 219 hectares that if to be consider 8,000 cubic meters of water per hectare, about 1.7 million cubic meter water has been consumed in this section.

\subsection{Water Consumptions in Agricultural and Horticultural Section}

According to Iran Water Resources Management Company, in the Alborz province has been occurred most harvest of groundwater resources for agricultural purposes in Hashtgerd area and amount of 51 percent of the whole harvest of groundwater resources. 
Table 4. The vast of cultivated area of Agricultural and horticultural land on segregated city in 2013.

\begin{tabular}{cccccc}
\hline Township & Savojbolagh & NazarAbad & Total & Province\& & Production in Province \\
\hline Agricultural & 10455 & 25363 & 35818 & 47905 & 75 \\
Horticultural & 14743 & 1844 & 16587 & 26023 & 64 \\
Total & 25198 & 27207 & 52405 & 73928 & 71 \\
\hline
\end{tabular}

Source: Agricultural Jihad Alborz.

\subsection{Need to Irrigation of Agricultural and Horticultural Products}

The net consumption of irrigation water of horticultural and agricultural products has been given in Table 5 and Table 6 respectively.

\subsection{Water Consumption of Agricultural and Horticultural Products in the Province}

Also required pure water levels in the study field and based on the pattern of cultivation of agricultural products and fertile horticultural products have been calculated and presented in Table 7. The under cultivation percentage level of various products in this calculation was effective, and in average for per hectare of agricultural plants under cultivation level 5378 cubic meters and per hectare of horticultural products under cultivation level 8856 cubic meters of water have been consumed (Table 8).

According to calculations in this study, the major provider of food needs of humans and livestock products (agricultural, fertile horticultural and greenhouse), have been consumed 339 million cubic meters of water in the region of Hashtgerd. Virtual water exports in agricultural and horticultural sector is 24.346 million cubic meters, virtual water import 68.75 million cubic meters of, and then virtual water trade balance of agricultural and horticultural products in the range of digital is 56.270 million cubic meters.

Agricultural lands density range, high performance products compared to national average as well as the district proximity to the country capital that large amount of agricultural production in the region, especially vegetables, cucurbits, and fruits are consumed in Tehran or in Karaj can be the main reasons for the positive balance of virtual water trade.

Calculations show that two townships of Savojbolagh and Nazarabad with about 64 percent of the horticultural lands and 75 percent of agricultural lands in the province have the highest share of agricultural consumption water of Alborz Province (Table 9). In such a way that about 40 percent of agricultural consumption water is consumed in this area. At least there is about 35 million cubic meters of low potential managed irrigation in the area study in Hashtgerd in 10 major products cultivation which are allocated $86 \%$ of consumption water of agricultural sector.

Virtual water exports in agricultural and horticultural sector in the study area in Hashtgerd is 24.346 million cubic meters that with respect to water consumption in greenhouse products gets to 348 million cubic meters. This water is mostly exported to Tehran and Karaj. Virtual water imports of this region is 75.68 million cubic meters and therefore virtual water trade balance of agricultural and horticultural products in the province in digital is +260 million cubic meters, it means 260 million cubic meters of virtual water is exited annually by agricultural products exports.

The most important water exported products in Hashtgerd range in order of importance are peaches and nectarines (33 percent of water exports), plums (15 percent of water exports), vegetables (5.14 percent of water exports), cherry (4.7 percent of water exports) and wheat (6.5 percent of water exports). The most water imported products of the range, in order of importance are rice (23 percent of virtual water imports) and citrus (19 percent of water import).

By 25 percent reduction in area under cultivation in peaches and nectarines or by 50 percent of the area under cultivation of these two products equipped with a drip irrigation system, about 16 million cubic meters of water will reduce consumption causing equilibrium in alluvial aquifer balance.

Therefore, regarding to negative water balance in the region and to balance incoming and outgoing water, it is necessary that the area under cultivation of products with high water consumption to be reduced such as alfalfa, tomatoes, cherries and apples as well as unconventional and non-essential products that have a high share in water consumption to be transferred into greenhouse such as vegetables and cucurbits so that in addition to optimum water consumption, their production level to be increased. 
Table 5. Water required and irrigation water for crops (excluding performance) in the study area (cubic meters ha).

\begin{tabular}{|c|c|c|c|c|}
\hline Product name & $\begin{array}{l}\text { Growth period } \\
\text { (day) }\end{array}$ & $\begin{array}{l}\text { Pure water } \\
\text { required }\end{array}$ & $\begin{array}{c}\text { Supplied water of } \\
\text { rain }\end{array}$ & $\begin{array}{c}\text { Need of net water to } 100 \% \\
\text { production }\end{array}$ \\
\hline Wheat & 240 & 5570 & 1790 & 3780 \\
\hline Barley & 230 & 5570 & 1790 & 3680 \\
\hline Maize & 130 & 7950 & 200 & 7750 \\
\hline Maize & 110 & 6510 & 70 & 6440 \\
\hline Alfalfa & 250 & 13,830 & 1060 & 12,770 \\
\hline Clover (spring planting) & 170 & 10,370 & 400 & 9970 \\
\hline Sunflower & 130 & 7830 & 290 & 7540 \\
\hline Sesame (Varamin) & 130 & 7520 & 140 & 7380 \\
\hline Canola & - & - & - & 3680 \\
\hline Peas & 110 & 4390 & 900 & 3600 \\
\hline Beans & 120 & 6870 & 120 & 6750 \\
\hline Lettuce and cabbage & - & - & - & 5850 \\
\hline Cucumbers & 100 & 4480 & 540 & 3940 \\
\hline Tomato & 150 & 8620 & 240 & 8380 \\
\hline Vegetables & - & - & - & 5600 \\
\hline Watermelon & 140 & 7680 & 200 & 7480 \\
\hline Melons (Varamin) & 140 & 7330 & 260 & 7110 \\
\hline Onions (Qazvin) & 150 & 8620 & 290 & 8330 \\
\hline
\end{tabular}

Source: required water estimation of agricultural and horticulture major plants, Farshi and colleagues. The Country National Water document has been used for grapes, lettuce and cabbage and vegetables. In this study, the irrigation method in which the entire surface of garden gets wet has been considered to calculate the annual water requirement of horticultural product. It should be noted that the value for the initial irrigation (water-soil) has not been included in the calculation of irrigation requirements.

Table 6. Water requirements and the need for irrigation water of horticultural products (excluding performance) in the study area (cubic meters ha).

\begin{tabular}{|c|c|c|c|c|c|}
\hline Product name & $\begin{array}{l}\text { Growth period } \\
\text { (day) }\end{array}$ & $\begin{array}{l}\text { Net water } \\
\text { required }\end{array}$ & $\begin{array}{l}\text { Water supply of } \\
\text { rainfall }\end{array}$ & $\begin{array}{c}\text { Need of net } \\
\text { irrigation water\# }\end{array}$ & $\begin{array}{c}\text { Need of net irrigation } \\
\text { water* }\end{array}$ \\
\hline Peach & 230 & 9700 & 1000 & 8700 & 6850 \\
\hline Apricots & 230 & 9700 & 1000 & 8700 & 6850 \\
\hline Pears & 230 & 9700 & 1000 & 8700 & 6850 \\
\hline Almonds & 230 & 7760 & 1000 & 6960 & 5480 \\
\hline Berry & 230 & 7760 & 1000 & 6960 & 5480 \\
\hline Apple & 230 & 11,300 & 840 & 10,460 & 8240 \\
\hline Cherry & 230 & 11,300 & 840 & 10,460 & 8240 \\
\hline Walnut & 230 & 11,300 & 840 & 10,000 & 8240 \\
\hline Grapes & --- & 8070 & 900 & 7170 & 5650 \\
\hline
\end{tabular}

\#The methods of irrigation in which the entire surface of garden gets wet. *The methods of irrigation in which part of the garden gets wet. Source: Required water estimation of agricultural and horticulture major plants, Farshi and colleagues. The Country National Water document has been used for grapes, lettuce and cabbage and vegetables.

Now the current area under cultivation of vegetables and cucurbits in the region is 6600 hectares, which consumes about 34 million cubic meters of water. If $50 \%$ of the considered area under cultivation is transferred to the greenhouse, the area under cultivation and consumption water will be reduced approximately 3,000 hectares and 30 million cubic meters respectively. 
Table 7. Net needs of Irrigation of agricultural and horticultural crops (million cubic meters per year).

\begin{tabular}{|c|c|c|c|c|c|c|c|}
\hline \multirow[b]{2}{*}{ Row } & \multicolumn{3}{|c|}{ Agricultural products } & \multirow[b]{2}{*}{ row } & \multicolumn{3}{|c|}{ *horticultural products } \\
\hline & Product name & $\begin{array}{c}\text { Area under } \\
\text { cultivation } \\
\text { (ha) }\end{array}$ & $\begin{array}{c}\text { Annual } \\
\text { irrigation } \\
\text { requirement } \\
(\mathrm{M} \cdot \mathrm{m} \cdot \mathrm{m})\end{array}$ & & Product name & $\begin{array}{l}\text { Area under } \\
\text { cultivation } \\
\text { (ha) }\end{array}$ & $\begin{array}{c}\text { Annual } \\
\text { irrigation } \\
\text { requirement } \\
(\mathbf{M} \cdot \mathbf{m} \cdot \mathbf{m})\end{array}$ \\
\hline 1 & Wheat & 10,557 & 90.39 & 1 & Apple & 1714 & 09.17 \\
\hline 2 & Barley & 7500 & 35.28 & 2 & Pears & 622 & 4.5 \\
\hline 3 & Forage maize & 8383 & 98.53 & 3 & Cherry & 1254 & 1.13 \\
\hline 4 & Alfalfa & 1862 & 77.23 & 4 & $\begin{array}{l}\text { Peaches and } \\
\text { nectarines }\end{array}$ & 7249 & 63 \\
\hline 5 & $\begin{array}{l}\text { Cabbage and } \\
\text { lettuce }\end{array}$ & 4064 & 77.23 & 5 & Walnut & 937 & 3.9 \\
\hline 6 & tomato & 964 & 07.8 & 6 & Plum varieties & 2788 & 2.4 \\
\hline 7 & Other vegetables & 235 & 3.1 & 7 & Grapes & 1138 & 1.8 \\
\hline 8 & Maize & 11 & 09.0 & 8 & Almonds & 306 & 1.2 \\
\hline 9 & Cucumbers & 7.94 & 4.0 & 9 & $\begin{array}{l}\text { Cherry and } \\
\text { other trees }\end{array}$ & 511 & 4 \\
\hline 10 & Peas & 669 & 34.3 & \multicolumn{2}{|c|}{ Total garden } & & 3.146 \\
\hline 11 & Melons & 15.5 & 11.0 & \multicolumn{2}{|c|}{ Total net volume irrigation } & & 4.337 \\
\hline 12 & An onion & 5.514 & 29.4 & & & & \\
\hline 13 & Canola & 100 & 37.0 & & & & \\
\hline 14 & Green beans & 487 & 28.3 & & & & \\
\hline 15 & Watermelon & 16 & 12.0 & & & & \\
\hline 16 & Other productions & 0 & 0 & & & & \\
\hline & Total crop & & 11.191 & & & & \\
\hline
\end{tabular}

Source: research findings.

Table 8. Net irrigation requirement of fertile agricultural and horticultural products (cubic meters per hectare) to separation of the study area in the crop year 2013-2014.

\begin{tabular}{cccc}
\hline & Products type & & Study area \\
\hline Horticultural & & Agricultural & Hashtgerd \\
\hline 8856 & & 5378 & \\
\hline
\end{tabular}

Source: research findings.

Regarding to water consumption for the production of forage maize and alfalfa and comparison of water use efficiency of these two products (respectively 7.3 and 6.0 kilograms per cubic meter) and also due to importance of animal husbandry in the province, an increase of area under cultivation of forage maize in the province due to better performance and less water consumption has relative advantage and reduces forage imports and it seems reasonable. Due to the relative advantage of forage maize compared to alfalfa, regional farmers have increased area under cultivation of this products compared to alfalfa properly in current years.

\section{Suggestions}

1) It is recommended that methods such as increasing water productivity at the farm level which has been a priority of the relevant organs for years optimized and modified by combination of correction procedures cultivation applying on cultivation pattern based on virtual water consumption level in different situations, modifying consumption patterns in the community which has been emphasized on it in Arabic study by Yazdi and Nik ta [9], no increase in area under cultivation in the basin aquifers under water stress, optimizing the cultivation methods and using the concept of virtual water trade to control the export volume of water through this way.

2) Also it is recommended in this area, especially in areas where the forage maize performance is less than 40 tons per hectare, sorghum cultivation is replaced. Due to the multiplicity of animal husbandry units in the 
Table 9. Identification and analysis of water consumption and trade of agricultural and horticultural crops in 2012-2013 Alborz Province (population: 220 thousand).

\begin{tabular}{|c|c|c|c|c|c|c|c|c|c|}
\hline Product name & $\begin{array}{l}\text { The area } \\
\text { under } \\
\text { cultivation } \\
\text { (ha) }\end{array}$ & $\begin{array}{l}\text { Production } \\
\text { (Ton) }\end{array}$ & $\begin{array}{l}\text { Performance } \\
\text { (kg/ha) }\end{array}$ & $\begin{array}{l}\text { Water needed } \\
\text { to produce one } \\
\text { kg of product } \\
\left(\mathbf{m}^{3}\right)\end{array}$ & $\begin{array}{l}\text { Per capita } \\
\text { consumption of } \\
\text { the product } \\
\text { (kg/year) }\end{array}$ & $\begin{array}{c}\text { Total } \\
\text { amount } \\
\text { needed } \\
\text { (tons) }\end{array}$ & $\begin{array}{l}\text { The surplus or } \\
\text { deficit } \\
\text { Consumption } \\
\text { (tons) }\end{array}$ & $\begin{array}{c}\text { Water } \\
\text { requirements } \\
\text { for consumer } \\
\text { surplus or } \\
\text { deficit (MCM) }\end{array}$ & $\begin{array}{c}\text { Virtual } \\
\text { water } \\
\text { exported } \\
\text { (MCM) }\end{array}$ \\
\hline Wheat & 10,557 & 48,865 & 5000 & 1.36 & 158.1 & 34,782 & 14,083 & 19.2 & $19.2+$ \\
\hline Corn & 11 & 110 & 10 & 1.44 & 1.54 & 338 & $228-$ & 0.33 & $0.33-$ \\
\hline Rice & 0 & 0 & - & 1.87 & 42.7 & 9394 & 9394- & 17.5 & $17.5^{-}$ \\
\hline Pea & 0 & 0 & 0 & 1.48 & 4.16 & 915 & 915- & 1.3 & $1.3^{-}$ \\
\hline Sugar beet & 0 & 0 & - & 0.55 & 73.66 & 16,205 & $16,205^{-}$ & 8.9 & $8.9-$ \\
\hline potato & 0 & 0 & 0 & 0.88 & 49.23 & 10,830 & $10,830-$ & 9.5 & $9.5^{-}$ \\
\hline tomato & 964 & 45,800 & 48,000 & 0.45 & 50.15 & 11,033 & $34,767+$ & 15.6 & $15.6^{+}$ \\
\hline Onion & 514.5 & 30,870 & 60,000 & 0.37 & 22.64 & 4980 & $25,890+$ & 9.6 & $9.6+$ \\
\hline Vegetables & 4300 & 344,000 & 82,000 & 0.15 & 24.63 & 5419 & $338,581+$ & 50.7 & $50.7+$ \\
\hline Melons & 15.5 & 666 & 43,000 & 0.29 & 16.36 & 3600 & $2934-$ & 0.85 & $0.85-$ \\
\hline Watermelon & 16 & 720 & 45,000 & 0.28 & 32 & 7040 & $6320-$ & 1.7 & $1.7-$ \\
\hline Apple & 1714 & 34,280 & 20,000 & 0.92 & 28.19 & 6202 & $28,078+$ & 25.8 & $25.8+$ \\
\hline Grapes & 1138 & 22,077 & 19,400 & 0.62 & 28.63 & 6300 & $15,777+$ & 9.8 & $9.8^{+}$ \\
\hline Cherry & 1254 & 15,048 & 12,000 & 1.43 & 2.71 & 596 & $14,452+$ & 20.6 & $20.6+$ \\
\hline Pears & 622 & 14,928 & 24,000 & 0.86 & 1.87 & 412 & $14,516+$ & 12.5 & $12.5^{+}$ \\
\hline $\begin{array}{c}\text { Peaches and } \\
\text { nectarines }\end{array}$ & 7249 & 181,225 & 25,000 & 0.64 & 8.2 & 1804 & $179,421+$ & 114.8 & $114.8^{+}$ \\
\hline Plum varieties & 2788 & 61,336 & 22,000 & 0.86 & 6.18 & 1359 & $59,977+$ & 51.6 & $51.6+$ \\
\hline Walnut & 937 & 2811 & 3000 & 6.66 & 2.13 & 469 & $2342+$ & 15.6 & $15.6^{+}$ \\
\hline Date & 0 & 0 & - & 3.22 & 10.08 & 2217 & $2217-$ & 7.1 & $7.1-$ \\
\hline Citrus & 0 & 0 & - & 1.25 & 51.6 & 11,352 & $11,352-$ & 14.2 & $14.2-$ \\
\hline Pomegranate & 0 & 0 & - & 5.84 & 9.8 & 2156 & $2156-$ & 12.6 & $12.6^{-}$ \\
\hline Banana & 0 & 0 & - & 2 & 4 & 880 & $880-$ & 1.7 & $1.7-$ \\
\hline $\begin{array}{l}\text { Almond and } \\
\text { other trees }\end{array}$ & 817 & 4000 & -- & 1.0 & 2 & 440 & $440+$ & 0.44 & $0.44+$ \\
\hline \multicolumn{4}{|c|}{ Virtual water exports: 345.24 million cubic meters } & \multicolumn{6}{|c|}{$\begin{array}{l}\text { Virtual water trade balance } 270.56+ \\
\text { million cubic meters }\end{array}$} \\
\hline
\end{tabular}

Source area under cultivation of production and performance: Jahade Keshavarzi Organization in Alborz Province.

Capita consumption: food balance sheets of the Islamic Republic of Iran.

Required pure water for irrigation (cubic meters per hectare): National Water Document and the provincial syntheses and calibration by experts research Other columns: Research Findings *-Numbers in the fourth column (related to the performance) in case of virtual water imports are the country performance mean and in the case of virtual water exports are the province performance.

study area, it is worthy that the livestock products and its role in water consumption and export of virtual water will be calculated in further studies.

3) Optimum cultivation pattern in Hashtgerd region based on the potential of water resources, region lands talent, farmer economic profit and the need and the consumer market of agricultural products is to be determined by mathematical programming methods. At this particular, Nematollahi et al. in Dashte Mashhad, Mohammadi and colleagues in Marvdasht, Fars and Akbari and Zahedi in Hamedan achieved good results [10] [11].

\section{References}

[1] Aldaya, M.M., Santos. P.M. and Llamas, M.R. (2010) Incorporating the Water Footprint and Virtual Water into Policy: Reflections from the Manta Occidental Region. Spain. Water Resource Management, 24, 941-958. http://dx.doi.org/10.1007/s11269-009-9480-8

[2] Hoekstra, A.Y. and Chapagain, A.K. (2008) Globalization of Water: Sharing the Planet's Freshwater Resources. Blackwell Publishing, Oxford. 
[3] Farshi, A.A., Shariati, M.R. and jarollahi, R. (1997) Estimates of Crop \& Garden Plants Water Requirement. Agricultural Education Publishing, 20-25 \& 690-699.

[4] Hoekstra (2008) Water Neutral: Reducing and Offsetting the Impacts of Water Footprints. Value of Water. Research Report Series No. 28, 42.

[5] Hoekstra, A.Y., Chapagain, A.K., Aldaya, M.M and Mekonnen, T.M. (2009) Water Footprint Manual. State of the Art, Web. 131. www.waterfootprint.org

[6] Hedari, N. (2011) Determination and Evaluation of Water Use Efficiency of Crops, Managed by Farmers. Journal of Water Management and Irrigation, 2, 43-57. (In Farsi)

[7] Tehran Regional Water Company (2013) The Water Balance Report of Hashtgerd Study Area. www.albrw.ir/

[8] Alborz Province Agriculture of Jahad Organization (2015) The Final Report 2015.

[9] Web Pages and On-line Material: ArabiYazdi, A. and Nikta, N. (2012) Study of Virtual Watertradein South Khorasan Province and Its Impact on Aquifers. South Khorasan Regional Water Company. http://www.skhrw.ir/

[10] Mohammadi, H. and Bostani, F. (2011) Determine Optimal Crop Pattern by Algorithm Multi-Objective Optimization Fuzzy. Journal of Water and Wastewater, 4, 43-54.

[11] Nematollahi, M.R. (2014) Determine the Optimum Model to Achieve Ecological Management of Mashhad Plain Crops. Ph.D. Thesis, College Agriculture \& Natural Resources, University of Tehran, Karaj. 